$\begin{array}{r}\text { Phinisi Integration Review } \\ \text { Vol. 2, No.2, Agustus 2019 Hal 185-200 } \\ \text { Website: } \underline{\text { http://ojs.unm.ac.id/pir }} \\ \text { p-ISSN: 2614-2325 dan e-ISSN: 2614-2317 } \\ \text { DOI: https://doi.org/10.26858/pir.v2i2.9981 } \\ \hline\end{array}$

\title{
Patuntung Sebagai Kepercayaan Masyarakat Kajang Dalam (Ilalang Embayya) Di Kabupaten Bulukumba
}

\author{
Hasan $^{1}$, Hasruddin Nur ${ }^{2}$ \\ ${ }^{1}$ Antropologi, SMA Negeri 5 Bulukumba \\ Email: hasannawir@gmail.com \\ ${ }^{2}$ Sosiologi, Universitas Sawerigading Makassar \\ ${ }^{2}$ Email: asrul23.23.a2@gmail.com
}

\begin{abstract}
Abstrak. Penelitian ini bertujuan untuk mengkaji dan menganalisis ; (1) eksistensi Patuntung sebagai ajaran masyarakat Kajang Dalam (ilalang embayya); (2) fungsi Patuntung bagi masyarakat Kajang Dalam (ilalang embayya); (3) bentuk aplikasi Patuntung dalam kehidupan masyarakat Kajang Dalam (ilalang embayya). Penelitian ini adalah penelitian kualitatif dengan menggunakan teknik pengumpulan data observasi, wawancara, dan dokumentasi. Teknik penentuan dan pengambilan sasaran informan dilakukan dengan teknik purposive sampling. Maksudnya, penentuan sampel informan ditentukan dengan sengaja berdasarkan kriteria masyarakat Kajang Dalam yang bertempat tinggal di dalam Kawasan Adat Ammatoa maupun di luar Kawasan Adat Ammatoa. Analisis data dilakukan secara deskriptif kualitatif melalui tahap reduksi data, penyajian data, serta verifikasi data. Hasil penelitian menunjukkan, bahwa Patuntung sebagai kepercayaan masyarakat Kajang Dalam (ilalang embayya) (1) kepercayaan Patuntung pertama kali dimulai dari munculnya manusia pertama yakni ammatoa (bohe pertama) dengan sumber ajarannya Pasang ri Kajang yang mengajarkan hidup sederhana, hidup dalam keadaan bersih, sembahyang secara terus menurus, dan ritual-ritual dalam ajaran Patuntung masih dilakukan sampai sekarang; (2) berfungsi sebagai ajaran, penyelamat, kontrol sosial, dan pemersatu, (3) sebagai aplikasi kepercayaan Patuntung dalam hubungan dengan Tu Rie A'rakna (Allah SWT), hubungan dengan tallasa kamase-mase (hidup sederhana), dan hubungan dengan lingkungan alam. Oleh karena itu, berdasarkan temuan yang telah diperoleh disarankan agar masyarakat Kajang Dalam (ilalang embayya) ajaran Patuntung yang pada hakikatnya harus direalisasikan dengan memadukan syariat agama Islam, pemerintahan dengan Adat Ammatoa sekiranya tetap melestarikan atau menjaga nilai-nilai ajaran Patuntung agar tidak tergerus oleh arus globalisasi, dan bagi pembaca, materi dari hasil tesis ini dapat dijadikan sebagai pengetahuan untuk menanamkan sikap tallasa kamase-masea (hidup sederhana) sebagai jalan hidup dan bagi peneliti selanjutnya dapat dijadikan referensi.
\end{abstract}

Kata Kunci : Patuntung; Masyarakat Kajang Dalam.

Abstract. The study aims at examining and analyzing (1) the existence of Patuntung as the
teaching of Kajang Dalam people (ilalang embayya), (2) the function of Patuntung as the
teaching of Kajang Dalam people (ilalang embayya), and (3) the application form of
Patuntung as the teaching of Kajang Dalam people (ilalang embayya). The study was a
qualitative research. Data were collected through observation, interview, and
documentation. The technique used in determining and obtaining the informant was
conducted by employing purposive sampling based on the criteria of Kajang Dalam people
who resided at Ammatoa Custom Area and outside of the area. Data was analyzed using 
descriptive qualitative by conducting stage of data reduction, data presentation, and verification data. The results of the study reveal that the Patuntung as the belief of Kajang Dalam people (ilalang embayya) (1) it was started from the first human, ammatoa (first bohe) with teaching source of Pasang ri Kajang the teaches a simple life, pure life, non stop praying, and the rituals in Patuntung teaching are still conducted to date, (2) the functions are as the teaching, savior, social control, and unifier, and (3) it is as application of belief of Patuntung in a relationship with Tu Rie A'rakna (Allah SWT), relationship with tallasa kamase-mase (simple life), and relationship with environment. Therefore, based on the results of the study, it is suggested that Kajang Dalam people (ilalang embayya) of Patuntung teaching should be realized into an integration of syariat Islam, the government and ammatoa custom should maintain the values of Patuntung teaching as not to eroded by globalization, as for the readers, the result of this study will help expanding the knowledge to instill tallasa kamase-masea attitude (simple life) as a lifestyle, and finally the next researcher way take this study as a valuable reference.

Keywords: Patuntung Kajang Dalam people

Ini adalah artikel dengan akses terbuka dibawah licenci CC BY-NC-4.0

(https://creativecommons.org/licenses/by-nc/4.0/ )

\section{PENDAHULUAN}

Indonesia merupakan negara majemuk dan multikultural yang kaya dengan khazanah keberagaman suku, agama, ras, dan kepercayaan yang tersebar dari Sabang sampai Marauke. Tidaklah mengeherankan jika Indonesia memiliki semboyan "Bhineka Tunggal Ika" (berbeda-beda tetapi tetap satu jua). Di antara keberagaman yang ada tersebut, kepercayaan merupakan topik yang menarik dan memiliki posisi yang berperan penting dalam semua aspek kehidupan individu dan kolektif sebagai bagian dari identitas warga negara.Hal ini tampak jelas dalam rumusan Pancasila, yaitu sila pertama (Ketuhanan Yang Maha Esa), yang mendeskripsikan hubungan antara manusia dengan Tuhan sebagai dasar kehidupan.

Adanya kebebasan setiap warga negara Indonesia dalam memeluk dan menjalankan tuntunan kepercayaan dalam dimensi keagamaan, masing-masing dijamin dan dilindungi Undang-Undang Dasar RI 1945, yaitu pada pasal 29 ayat 2, yang berbunyi: "negara menjamin kemerdekaan tiap-tiap penduduk untuk memeluk agamanya masingmasing dan untuk beribadah menurut agama dan kepercayaannya itu" (UUD 1945).

Istilah agama dan kepercayaan memiliki makna yang berbeda antara satu dengan yang lain. Kata agama di Indonesia merujuk pada enam agama besar yang resmi diakui di antaranya Islam, Kristen Protestan, Kristen Katholik, Hindu, Kegiatan keagamaan yang dipraktekkan oleh berbagai suku bangsa di Indonesia dalam berbagai upacara adat ataupun terhadap pemujaan roh leluhurnya dianggap sebagai aliran kepercayaan, seperti animisme dan dinamisme. Namun setelah masuknya agama-agama besar (Hindu, Budha, Kristen, dan Islam), kepercayaan animisme dan dinamisme berangsur-angsur surut, meskipun tidak hilang sama sekali. Mereka yang telah menganut agama-agama besar, tradisi animisme dan dinamisme masih dipraktekkan sampai sekarang. Beberapa masyarakat Indonesia yang tinggal di pedesaan atau di pedalaman masih meyakini, bahwa keberadaan roh para leluhur mereka masih sangat berpengaruh pada lingkungan kehidupan mereka, dan aliran kepercayaan ini masih dijaga dan dilestarikan sampai sekarang oleh suku-suku bangsa tertentu (Rohmah, 2016:48).

Pada khususnya masyarakat Sulawesi Selatan, terdapat beberapa komunitas adat yang memiliki identitas sistem kepercayaan yang mereka anut, seperti di Toraja dikenal dengan Aluk Todolo dengan sistem kepercayaan terhadap Tuhan yang disebut Puang Matoa; di Sidrap dikenal dengan Toani Tolotang dengan sistem kepercayaan terhadap Tuhan yang disebut Dewata Seuwae yang bergelar Patotoe; dan di Kajang dikenal Patuntung dengan sistem 
kepercayaan kepada Tuhan yang disebut Turie' A'rakna.

Pengakuan atas kepercayaan terhadap Tuhan, telah ada sejak sebelum kedatangan agama-agama besar tersebut, sehingga dalam ritual keagamaan masih terdapat aliran kepercayaan yang diadopsi di dalam pelaksanaannya. Hal ini tampak dalam masyarakat Sulawesi Selatan sampai saat ini.

Di antara kabupaten yang ada di Sulawesi Selatan, Kabupaten Bulukumba merupakan kabupaten yang memilliki satu desa yang unik (memiliki citra identitas pakaian berwarna hitam) dan khas (hidup dalam kesederhanaan), yaitu Kawasan Adat Ammatoa yang terletak di Desa Tanatoa, Kecamatan Kajang, Kabupaten Bulukumba. Kawasan Adat Ammatoa adalah sebuah pemukiman masyarakat yang kental dengan nuansa tradisional dan mencitrakan kehidupan masyarakat yang masih sederhana. Hal ini tampak dari aktivitas keseharian masyarakatnya dan sistem mata pencaharian kehidupan mereka yang masih bergantung pada kondisi alam dan lingkungan sekitarnya.

Kawasan Adat Ammatoa adalah tempat permukiman masyarakat Kajang Dalam yang tinggal secara berkelompok dalam sebuah lingkungan hutan dengan satu asal-usul nenek moyang yang sama. Dimana hutan dan isinya dijadikan sumberdaya dalam memenuhi kebutuhan sehari-hari.

Menurut Peraturan Daerah Kabupaten Bulukumba Nomor 9 Tahun 2015, Tentang pengukuhan, pengakuan hak, dan perlindungan hak Masyarakat Hukum Adat Ammatoa Kajang. Masyarakat Hukum Adat (MHA) Ammatoa Kajang adalah sekelompok orang yang secara turun-temurun bermukim di Ilalang Embayya (di dalam Kawasan Adat Ammatoa) dan sebagian bermukim di Ipantarang Embayya (di luar Kawasan Adat Ammatoa).

Munculnya dua kelompok masyarakat di Desa Tanatoa adalah atas penolakan ajaran Islam yang dibawa oleh Janggo Tojarra dan Tu Asara Daeng Mallipa oleh ammatoa dan komunitasnya itulah yang melatarbelakangi terbentuknya dualisme komunitas Kajang yaitu; (1) komunitas ammatoa yang lazin disebut masyarakat Kajang Dalam Embayya yang menganut kepercayaan patuntung, dan 2) komunitas di Luar Embayya atau lazin disebut masyarakat Kajang Luar Embayya. Dualisme masyarakat Kajang hinga dewasa ini masih terlihat perbedaan yang nampak antara kedua komunitas, masyarakat Kajang Dalam Embayya masih tetap menegakkan ajaran Pasang ri Kajang sebagai pedoman hidup dalam kehidupan sehari-hari, sedangkan masyarakat Kajang Luar Embayya menjadikan Al-Qur'an dan Hadist sebagai pedoman hidup dalam kehidupan sehari-hari. Sambu (2016:26)

Kedua kelompok masyarakat yang bermukim di Desa Tanatoa, terdapat perbedaan yang tampak menonjol adalah persoalan mengenai pandangan hidup, yaitu kelompok masyarakat yang masingmasing berpegang teguh pada ajaran agama Islam sebagai pedoman dalam berkehidupan mereka, yakni kelompok masyarakat Ipantarang Embaya, tetapi juga menganut aliran kepercayaan Patuntung meskipun tidak seperti masyarakat Ilalang Embayya. Masyarakat Kajang Dalam (ilalang embayya) yang kental menanamkan pada diri mereka dengan menganut aliran kepercayaan Patuntung secara mendalam atau sering juga disebut masyarakat penganut aliran kepercayaan Kajang.

Selain pandangan hidup yang berbeda juga tampak satu prinsip hidup yaitu tallasa kamase mase (hidup sederhana) pada masyarakat Kajang Dalam (ilalang embayya) dapat dilihat dalam kehidupan sehari-harinya yaitu tidak menggunakan alas kaki, pakaian hanya warna hitam dan putih, begitupun bola (rumah) baik bentuk, bahan dan arah bangunan yang sama yaitu menghadap ke barat, semua itu terkait dengan ajaran patuntung yang masih diyakini sampai sekarang. Sedangkan masyarakat Kajang Luar (ipantarang embayya) hidup secara berkecukupan atau hidup mengikuti perkembangan zaman dari waktu kewaktu dan dapat dilihat dalam kehidupan sehari-harinya sudah menggunakan sandal, sepatu, kendaraan bermotor, model dan bahan rumah beragam bahkan arah bangunan sama seperti pada umumnya.

Komunitas adat pada umumnya lahir, tumbuh, dan berkembang tidak berada dalam koridor menjalankan syariat ajaran dan tuntunan agama yang disyaratkan, meskipun secara administrasi mencantumkan salah satu agama Tuhan dalam kartu identitasnya (KTP), seperti halnya masyarakat kajang yang bermukim di Kawasan Adat Ammatoa, tumbuh dan berkembang dengan menganut aliran kepercayaan yang disebut Patuntung.

Pada masyarakat Kajang Dalam (ilalang embayya) yang bermukim di Kawasan Adat Ammatoa, menganut agama Islam, walaupun dalam implementasinya mereka tidak 
melaksanakan sesuai dengan syariat Islam pada umumnya seperti diantaranya shalat, puasa, dan berhaji. Namun, komitmen dan keyakinan mereka terhadap agama Islam cukup kuat, meskipun hanya sebatas pengakuan, dan belum menyentuh kehidupan keseharian mereka dalam praktek amaliah berdasarkan syariat keagamaan yang dimaksud.

Masyarakat Kajang Dalam (ilalang embayya), mengakui Islam sebagai agama mereka, tetapi praktek amaliahnya berbeda dengan syariat ajaran Islam. Sebagaimana yang dipahami dan dilaksanakan oleh masyarakat Islam pada umumnya. Dengan demikian, terjadi perbedaan pandangan dan praktek dalam menjalankan ajaran dan tuntunan agama antara masyarakat kawasan adat Ammatoa yang bertempat tinggal Ilalang Embayya dengan Ipantarang Embayya

Keseharian masyarakat ilalang embayya selaku penganut kepercayaan Patuntung, hal ini menurut mereka Patuntung bukan agama melainkan kepercayaan yang wajib dipatuhi dan dilaksanakan oleh setiap anggota masyarakat adat Ammatoa Kajang, sebagai "penuntut"atau "penuntun" untuk mengamalkan ajaran kebenaran yang diwasiatkan dan diwariskan secara lisan oleh para leluhur mereka secara turun-temurun dari generasi kegenerasi, dimulai dari yang pertama sampai yang terakhir. Wasiat inilah yang dikenal dengan sebutan Pasang ri Kajang Hafid (2003)

Masyarakat Kajang Dalam (ilalang embayya) memiliki dualisme kepercayaan, yakni Islam sebagai agama yang diakui negara dan kepercayaan Patuntung sebagai ajaran leluhur yang wajib dijalankan. Pemahaman ajaran agama Islam dikalangan mereka tidak didasarkan pada pemahaman syariat Islam, akan tetapi didasarkan pada kegiatan yang berkaitan dengan tarekat.

Wujud pemahaman masyarakat Kajang

Dalam (ilalang embayya), khususnya yang berdomisili di Kawasan Adat Ammatoa (iIalang embayya) yang ada kaitannya dengan tarekat adalah mengamalkan jenne taluka dan sembahyang tamattappuka, yang artinya wudhu yang tidak pernah batal dan shalat yang tidak pernah terputus. Dari ungkapan ini, dapat dipahami bahwa dengan berbuat amal kepada sesama manusia, berarti sudah melaksanakan shalat dan kegiatan keagamaan lainnya sesuai dengan syariat Islam menurut perspektif mereka. Kepercayaan Patuntung mengamalkan Pasang ri Kajang sebagai sumber keyakinan dan kepercayaan masyarakat Kajang Dalam (ilalang embayya).

\section{TINJAUAN PUSTAKA}

\section{Agama dan Kebudayaan}

Agama merupakan sesuatu yang sulit dipisahkan dari kehidupan manusia. Hal tersebut terjadi karena di dalam hidupnya, manusia selalu memiliki pertanyaan-pertanyaan mengenai makna hidup. Manusia juga mengalami situasi yang membuatnya berpikir akan sesuatu melampaui dirinya. Di situlah agama menawarkan jawaban-jawaban atas pertanyaan manusia. Jadi agama adalah sesuatu yang sudah menjadi kebutuhan manusia sebagai bagian dari spiritualitas diri dalam penghambaan atas penciptanya.

Menurut Koentjaraningrat, (1992:230) mendefinisikan bahwa agama adalah suatu sikap hidup yang membuat orang mampu mengatasi kesulitan sebagai manusia, dengan memberikan jawaban kepuasan spiritual pada pernyataan mendasar tentang teka-teki alam semesta dan peranan manusia didalamnya, dengan memberikan ajaran praktis untuk hidup di alam semesta.

Lebih jelas lagi sebagaimana menurut Anthony F.C. Wallace (Koentjaraningrat, 1980:68) mengatakan bahwa agama merupakan seperangkat upacara yang diberi mitos-mitos, dan menggerakkan kekuatan-kekuatan supranatural dengan tujuan untuk mencapai sesuatu atau yang merugikan pada kondisi manusia dan alam. Defenisi itu mengandung suatu pengakuan bahwa, jika tidak dapat mengatasi masalah serius yang menimbulkan kegelisahan mereka, manusia berusaha mengatasinya dengan memanipulasi makhluk dan kekuatan supernatural. Untuk itu digunakan upacara keagamaan, yang oleh Wallace dipandang sebagai gejala agama yang utama atau agama sebagai perbuatan.

Sedangkan kebudayaan dalam kehidupan sehari-hari, yaitu arti yang terbatas kepada hal-hal yang bersifat indah, seperti candi, tari-tarian, seni rupa, kesusastraan dan filsafat, dalam ilmu antropologi jauh lebih luas sifat dan ruang lingkupnya. Menurut (Koentjaraningrat, 2000: 181) kebudayaan dengan kata dasar budaya berasal dari bahasa sansakerta "buddhayah", yaitu bentuk jamak dari buddhi yang berarti "budi" atau "akal". Jadi Koentjaraningrat mendefinisikan budaya 
sebagai "daya budi" yang berupa cipta, karsa dan rasa, sedangkan kebudayaan adalah hasil dari cipta, karsa, dan rasa itu.

Koentjaraningrat menerangkan bahwa pada dasarnya banyak yang membedakan antara budaya dan kebudayaan, dimana budaya merupakan perkembangan majemuk budi daya, yang berarti daya dari budi. Pada kajian Antropologi, budaya dianggap merupakan singkatan dari kebudayaan yang tidak ada perbedaan dari definsi. Jadi kebudayaan atau disingkat budaya, menurut Koentjaraningrat merupakan keseluruhan sistem gagasan, ide-ide, tindakan dan hasil karya manusia dalam rangka kehidupan masyarakat yang dijadikan milik diri manusia dengan belajar.

Untuk lebih jelasnya mengenai hal diatas, (Koentjaraningrat,1985:186-187) membedakan adanya tiga wujud dari kebudayaan yaitu: (1) Wujud kebudayaan sebagai sebuah kompleks dari ide-ide, gagasan, nilai- nilai, norma-norma, peraturan dan sebagainya. (2) Wujud kebudayaan sebagai suatu kompleks aktivitas serta tindakan berpola dari manusia dalam suatu masyrakat. (3) Wujud kebudayaan sebagai benda-benda hasil karya manusia.

2. Munculnya Patuntung sebagai Kepercayaan

Kata "kepercayaan" menurut makna kata mempunyai beberapa arti, seperti iman kepada agama, anggapan (keyakinan), bahwa benar sungguh ada, misalnya kepada dewa-dewa dan orang-orang halus. Kata kepercayaan menurut istilah yang dimaksud di sini adalah keyakinan kepada Tuhan Yang Maha Esa, di luar agama atau yang tidak termasuk ke dalam agama (Kartapradja, 1985: 1).

"Teori Asal Mula Religi atau kepercayaan", pada mulanya berasal dari seorang sarjana antropologi Inggris, E.B.Tylor, dan diajukan dalam kitabnya yang terkenal berjudul Primitive Cultures (1873). Menurut Tylor, (Koentjaraningrat, 1980: 48-50), asal mula religi atau kepercayaan adalah kesadaran manusia akan paham jiwa. Kesadaran akan paham itu disebabkan karena dua hal, yaitu :

a. Perbedaan yang tampak kepada manusia antara hal-hal yang hidup dan hal-hal yang mati. Suatu makhluk pada suatu saat bergerak-gerak, artinya hidup; tetapi tak lama kemudian makhluk tadi tak bergerak lagi, artinya mati. Demikianpun manusia lambat laun mulai sadar bahwa gerak dalam alam itu, atau hidup itu, disebabkan oleh suatu hal yang ada di samping tubuh- jasmani dan kekuatan itulah yang disebut jiwa.

b. Peristiwa mimpi. Dalam mimpinya manusia melihat dirinya di tempat-tempat lain daripada tempat tidurnya. Demikian manusia mulai membedakan antara tubuh jasmaninya yang ada di tempat tidur, dan suatu bagian lain dari dirinya yang pergi ke lain tempat. Bagian lain itulah yang disebut jiwa.

Sifat abstrak dari jiwa tadi menimbulkan keyakinan di antara manusia bahwa jiwa dapat hidup langsung, lepas dari tubuh jasmani. Pada waktu hidup, jiwa masih tersangkut kepada tubuh jasmani, dan hanya dapat meninggalkan tubuh waktu manusia tidur dan waktu manusia jatuh pingsan. Karena pada suatu saat serupa itu kekuatan hidup pergi melayang, maka tubuh berada di dalam keadaan yang lemah.Tetapi kata Tylor, walaupun melayang, hubungan jiwa dengan jasmani pada saat-saat seperti tidur atau pingsan, tetap ada.Hanya pada waktu seorang makhluk manusia mati, jiwa melayang terlepas, dan terputuslah hubungan dengan tubuh jasmani untuk selama-lamanya. Hal itu tampak nyata, kalau tubuh jasmani sudah hancur berubah debu di dalam tanah atau hilang berganti abu di dalam api upacara pembakaran mayat; maka jiwa yang telah merdeka terlepas dari jasmaninya itu dapat berbuat semau-maunya. Alam semesta penuh dengan jiwa-jiwa merdeka itu, yang oleh Tylor tidak disebut jiwa lagi, tetapi disebut spirit atau makhluk halus. Demikian pikiran manusia telah mentransformasi kesadarannya akan adanya jiwa menjadi kepercayaan kepada makhlukmakhluk halus.

Pada tingkat tertua di dalam evolusi religi atau kepercayaannya manusia begitu percaya bahwa makhluk-makhluk halus itulah yang menempati alam sekeliling tempat tinggal manusia. Makhluk-makhluk halus tadi, yang tinggal dekat sekeliling tempat tinggal manusia, yang bertubuh halus sehingga tidak dapat tertangkap panca indera manusia, yang mampu berbuat hal-hal yang tak dapat diperbuat manusia, mendapat suatu tempat yang amat penting di dalam kehidupan manusia sehingga menjadi obyek daripada penghormatan dan penyembahannya, dengan berbagai upacara berupa doa, sajian, atau korban. Agama serupa itulah yang disebut oleh Tylor animisme.

Pada tingkat kedua di dalam evolusi agama, manusia percaya bahwa gerak alam hidup itu juga disebabkan oleh adanya jiwa yang ada di belakang peristiwa dan gejala alam itu. 
Sungai-sungai yang mengalir dan terjun dari gunung ke laut, gunung yang meletus, gempa bumi yang merusak, angin taufan yang menderu, jalannya matahari di angkasa, tumbuhnya tumbuh-tumbuhan dan sebagainya, semuanya disebabkan oleh jiwa alam. Kemudian jiwa alam tadi itu dipersonifikasi serta dianggap oleh manusia seperti makhluk-makhluk dengan suatu pribadi, dengan kemauan dan pikiran. Makhlukmakhluk halus yang ada di belakang gerak alam serupa itu disebut dewa-dewa alam.

Pada tingkat ketiga di dalam evolusi religi atau kepercayaan, bersamaan dengan timbulnya susunan kenegaraan di dalam masyarakat manusia, timbul pula kepercayaan bahwa alam dewa-dewa itu juga hidup di dalam suatu susunan kenegaraan, serupa dengan di dalam dunia makhluk manusia. Demikian ada pula suatu susunan pangkat dewa-dewa mulai dari raja dewa sebagai yang tertinggi, sampai pada dewa-dewa yang terendah. Suatu susunan serupa itu lambat laun akan menimbulkan suatu kesadaran bahwa semua dewa itu pada hakekatnya hanya merupakan penjelmaan saja dari satu dewa yang tertinggi itu. Akibat dari kepercayaan itu adalah berkembangnya kepercayaan kepada satu Tuhan yang Esa, dan timbulnya agama-agama monotheisme.

Adapun kepercayaan patuntung dalam masyarakat Kajang baik ilalang embayya dan ipantarang embayya, menurut Tika (2013 : 4143), adalah sebuah kepercayaan yang di anut oleh warga Tanatoa Kajang sebelum masa Pra Islam. Kepercayaan patuntung adalah salah satu bentuk kepercayaan animisme sebelum Islam masuk ke negeri ini. Kepercayaan patuntung sangat berpegang teguh pada Pasang ri Kajang. Dalam Pasang ri Kajang disebutkan, bahwa alam semesta ini diciptakan oleh $\mathrm{Tu}$ Rie A'rakna. Pada masa Pra Islam dikenal dengan nama Dewa atau Batara. Setelah Islam masuk, Tu Rie A'rakna dimaksud Allah SWT.

Hal ini sesuai apa yang dijelaskan oleh, Akib (2003 : 36) bahwasanya kepercayaan patuntung yang hidup dan tumbuh dalam wilayah tu kamase-masea bukan lagi budaya spiritual tradisional murni, akan tetapi sudah mendapat pengaruh ide spiritual Islam. Sehingga Kepercayaan patuntung atau mannuntungi diartikan sebagai suatu sasaran yang lebih konkret (nyata) terhadap konsep keagamaan yaitu sikap atau cita-cita menuju (mencapai) kearah pengetahuan, upaya peningkatan kualitas keagamaan, penghayatan serta pemahaman "kasallangngang" (ke-islam-an) yang lebih baik dan sempurna.

Lebih lanjut dijelaskan Akib (2003 : 40) bahwa terdapat ada 4 unsur yang terkandung dalam sistem kepercayaan Patuntung yang terhimpung dalam Pasang ri Kajang sebagai berikut: (1) Ide tentang Tuhan atau wujud yang supra natural dan mencakup kekuatan gaib; (2) Ide tentang roh yang erat kaitannya dengan konsep mengenai hari kemudian, surga dan neraka; (3) Ide tentang etos kerja dan etika yang dimaksudkan untuk tujuan-tujuan yang religious ("kallo anjorengang" atau tendensi keakhiratan). Dan (4) Ide tentang asal usul terjadinya alam semesta.

Dalam kepercayaan Patuntung ini, berdasar pada Pasang ri Kajang menjadi kerangka acuan dalam pola berbuhungan bagi masyarakat Kajang Dalam (Ilalang Embayya), baik pola hubungan yang vertikal pada $T u$ Rie A'rakna (Allah SWT) maupun horizontal sesana makhluk. Dengan fungsi demikian pasang yang berisi pesan-pesan, petuah-petuah, pedoman atau petunjuk hidup untuk kebahagiaan untuk kebahagiaan dunia (etos kerja dan etika yang didominasi tendensi untuk ke-akhiratan) dan berisi pesan-pesan, petuah-petuah, pedoman atau petunjuk untuk mencapai kebahagiaan dihari kemudian. Segala ketentuan Patuntung dalam Pasang ri Kajang (Pesan di Kajang) merupakan suatu keharusan untuk dijadikan suatu kewajiban dalam wujud penyembahan kepada Tu Rie A'rakna.

\section{Teori yang Relevan}

Teori yang digunakan dalam mengkaji Patuntung sebagai kepercayaan masyarakat Kajang yang bermukim di Kawasan Adat Ammatoa, yaitu teori fungsionalisme struktural Talcot Parson. Teori fungsional memandang manusia dalam masyarakat ditandai oleh kebutuhan dan jenis kecenderugan bertindak. Demi kelanjutan hidupnya, manusia harus bertindak terhadap lingkungan, baik dengan cara menyesuaikan diri pada lingkungan itu atau menguasai dan mengendalikannya.

Teori fungsionalisme memandang sumbangan agama terhadap masyarakat dan kebudayaan berdasarkan atas karakteristik kepentingannya, yakni transendensi pengalaman sehari-harinya dalam lingkungan alam. Teori fungsional menumbuhkan perhatian pada sumbangan fungsional agama yang diberikan terhadap sistem sosial. (Wirawan, $2012: 50$ ).

Agama dengan kedekatannya pada suatu yang berada di luar jangkauan dan 
keyakinannya, bahwa manusia berkepentingan pada suatu pandangan realistis dengan memperlihatkan norma dan peraturan masyarakat sebagai bagian dari tatanan etis supra empiris yang lebih besar, telah ditetapkan, dan disucikan oleh kepercayaan dan praktik keagamaan, maka agama dalam hal ini telah mendorong penguatan pelaksanaanya. Menurut Parson ada empat persyaratan mutlak yang harus ada agar termasuk masyarakat bisa berfungsi. Keempat persyaratan itu disebut AGIL, singkatan dari Adaptation, Goal Attainment, Integration, dan Latensi. Demi keberlangsungan hidupnya, maka masyarakat harus menjalankan fungsi-fungsi tersebut (Wirawan, 2012: 51).

Teori fungsionalisme struktural yang pencetusnya adalah Talcot Parson. Asumsi dasar dari teori fungsionalisme struktural yang memandang masyarakat sebagai satu sistem yang terdiri dari bagian-bagian yang saling berhubungan satu sama lain dan bagian yang satu tidak dapat berfungsi tanpa adanya hubungan dengan bagian yang lainya. Perubahan yang terjadi pada satu bagian akan menyebabkan ketidakseimbangan dan pada giliranya akan menciptakan perubahan pada bagian lainya.

\section{METODE PENELITIAN}

Jenis penelitian ini merupakan penelitian kualitatif. Desain yang digunakan adalah deskriptif kualitatif. Deskriptif kualitatif merupakan suatu rancangan penelitian yang memaparkan fenomena secara alamiah atau menggambarkan objek penelitian berdasarkan pada fakta yang ada.

Pengertian penelitian kualitatif dikemukakan oleh Moleong (2012: 6), bahwa penelitian kualitatif merupakan penelitian yang bermaksud untuk memahami fenomena tentang apa yang dialami oleh subjek penelitian secara holistik, pendeskripsian dengan kata-kata dan bahasa, konteks alamiah, dan memanfaatkan berbagai metode ilmiah. Penelitian kualitatif memiliki bebera karakteristik, antara lain; (1) mengungkapkan gejala secara holistickontekstual melalui pengumpulan data dari latar alami dengan memanfaatkan peneliti sebagai instrumen kunci; (2) bersifat deskriptif dengan analisis induktif; (3) proses dan makna lebih ditampakkan; dan (4) laporannya berbentuk narasi-kreatif mendalam dan menunjukkan ciriciri naturalistic dan autentik.

Lokasi penelitian ini, yaitu Kawasan Adat Ammatowa (masyarakat Kajang Dalam),
Desa Tanatoa, Kecamatan Kajang, Kabupaten Bulukumba, Sulawesi Selatan. Hal yang melatarbelakangi penentuan lokasi dalam penelitian ini, yaitu

1. Masyarakat Kajang Dalam (ilalang embayya) masih kental dengan kehidupan sederhana meskipun mereka melakukan interaksi dengan masyarakat luar.

2. Masyarakat Kajang Dalam (ilalang embayya) memiliki kehidupan sosial yang bergantung pada kondisi alam sekitar lingkungannya dan kepercayaan yang berbeda dengan masyarakat lainnya yang ada di Kabupaten Bulukumba.

3. Bentuk aktivitas ritual upacara Patuntung memiliki daya tarik rasa ingin tahu karena memadukan kepercayaan dan keyakinan keagamaan (dualisme kepercayaan) yang dianut secara bersamaan.

Sumber data dalam penelitian ini, yaitu: a) data primer adalah data yang diperoleh secara langsung dari informan (masyarakat Kajang Dalam dengan kriteria: pemangku adat, tokoh masyarakat (intelektual dan agamawan), dan masyarakat yang berdiam di dalam Kawasan Adat Ammatoa; dan b) data sekunder adalah data yang diperoleh dari berbagai sumber, seperti buku, jurnal, artikel, dan penelitian ilmiah (tesis).

Teknik penentuan dan pengambilan sasaran informan dilakukan dengan teknik purposive sampling, yakni teknik mengambil sampel sumber data dengan pertimbangan tertentu (Sugiyono, 2014: 300). Maksudnya, penentuan sampel informan ditentukan dengan sengaja berdasarkan kriteria masyarakat Kajang Dalam yang bertempat tinggal di dalam Kawasan Adat Ammatoa (pemangku adat, tokoh masyarakat (intelektual dan agamawan), dan masyarakat umum. Adapun informan dalam penelitian ini adalah :

1. Ammatoa sebagai pimpinan tertinggi dalam kawasan adat Ammatoa dianggap sebagai seorang kepala atau pimpinan adat

2. Galla Lombo sebagai wali Ammatoa di dalam dan di luar Kawasan adat Ammatoa yang merupakan Kepala Desa Tanatoa Kajang.

3. Galla Kajang sebagai orang yang mengurusi masalah agama dan sebagainya.

4. Galla Puto sebagai juru bicara Ammatoa

5. Masyarakat Kajang Dalam (ilalang embayya) dan Masyarakat Kajang Luar (ipantarang embayya) yang kompoten 
menjelaskan hal-hal yang dibutuhkan dalam penelitian ini.

Teknik pengumpulan data adalah langkah yang paling utama dalam penelitian, dengan tujuan utama penelitian untuk mendapatkan data. Sugiyono (2007: 309) menyatakan bahwa dalam penelitian kualitatif, pengumpulan data dilakukan pada kondisi yang alamiah sumber data primer, dan teknik pengumpulan data lebih banyak pada observasi berperanserta, wawancara mendalam dan dokumentasi.

Adapun metode atau cara yang peneliti gunakan dalam pengumpulan data nantinya adalah pengamatan, wawancara mendalam dan dokumentasi sebagai berikut:

\section{Teknik Pengamatan (observation)}

Observasi merupakan metode pengumpulan data dalam penelitian masyarakat dengan melihat dan mendengar gejala-gejala sosial yang menjadi obyek penelitian yang kemudian dianalisis dan diinterpretasi lebih lanjut. Koentjaraningrat (1997 : 162) mengatakan bahwa observasi merupakan metode penelitian masyarakat dengan melihat, mendengar, serta mencatat kejadian dan gejala sosial yang menjadi sasaran dengan melibatkan diri ke dalam aktivitas-aktivitas yang berkaitan dalam jangka waktu tertentu.

Teknik observasi adalah teknik yang menitik beratkan peran langsung peneliti dalam kegiatan penelitian (Sugiyono, 2008: 64). Untuk memperoleh data, peneliti akan melakukan observasi langsung (observasi partisipatif) dengan menggali data dari narasumber atau informan yang telah dtentukan sebelumnya dalam penelitian ini.

\section{Wawancara}

Wawancara dilakukan secara langsung terhadap informan yang berkompeten untuk menghimpun bahan-bahan keterangan yang dilaksanakan dengan tanya jawab dengan arah tujuan yang telah ditentukan (Munarfah dan Hasan, 2009: 83). Wawancara ini dilakukan secara bebas dan leluasa yang biasannya disebut dengan wawancara tidak terstruktur, agar data yang diperoleh lebih meluas dan menghimpun data secara mendalam dari informan yang diwawancarai.

Menurut Koentjaraningrat " wawancara adalah sutu teknik pengumpulkan data, merupakan suatu cara yang digunakan seseorang untuk tujuan suatu tugas tertentu, mencoba mendapatkan keterangan atau pendirian secara lisan dari seseorang responden, dengan cara bercakap-cakap berhadapan muka dengan orang itu" teknik ini digunakan untuk mencari keterangan lengkap (Koentjaraningrat,1997: 162)

\section{Dokumentasi}

Teknik ini merupakan catatan peristiwa yang sudah berlalu. Dokumentasi ini mengumpulkan data berupa dokumen (tertulis dari catatan saat melakukan wawancara, gambar/foto pada saat berada di lokasi penelitian, buku, dan lainnya) yang berkaitan dengan penelitian ini. Teknik dokumentasi yakni pengambilan data yang diperoleh dari informasiinformasi, buku-buku dan dokumen-dokumen yang berhubungan dengan objek yang diteliti. Menurut Suharsini Arikunto teknik studi dokumentasi adalah mencari data mengenai hal-hal atau variabel yang berupa catatan, transkrif, buku, surat kabar, Majalah, notulen, dan agenda. (Suharsimi Arikunto,1998: 135).

Teknik analisis data yang digunakan peneliti menggunakan model Miles and Huberman. Analisis data dalam penelitian kualitatif, dilakukan pada saat pengumpulan data berlangsung, dan setelah selesai pengumpulan data dalam periode tertentu. Pada saat wawancara, peneliti sudah melakukan analisis terhadap jawaban yang diwawancarai. Miles and Huberman (1984), mengemukakan bahwa aktivitas dalam analisis data kualitatif dilakukan secara interaktif dan berlangsung secara terus menerus sampai tuntas, sehingga datanya sudah jenuh. Aktivitas dalam analisis data, yaitu, data reduction, data display, dan conclusion drowing/verification (Sugiyono, 2007:246). Teknik analisis data pada penelitian ini penulis menggunakan tiga prosedur perolehan data yaitu:

1. Reduksi Data

Reduksi data adalah proses penyempurnaan data, baik pengurangan terhadap data yang dianggap kurang perlu dan tidak relevan, maupun penambahan data yang dirasa masih kurang. Data yang diperoleh di lapangan mungkin jumlahnya sangat banyak.

Reduksi data berarti merangkum, memilih hal-hal yang pokok, memfokuskan pada hal-hal yang penting, dicari tema dan polanya. Dengan demikian data yang akan direduksi memberikan gambaran yang lebih jelas, dan mempermudah peneliti untuk melakukan pengumpulan data selanjutnya, dan mencarinya bila diperlukan (Sugiyono, 2007:247). Jadi data dari lapangan berupa sumber lisan maupun tertulis yang kemudian 
ditulis direduksi, dirangkum, difokuskan kepada hal yang berhubungan dengan objek yang akan diteliti yakni munculnya Patuntung sebagai ajaran masyarakat Kajang Dalam (ilalang embayya), fungsi dan bentuk aplikasi dalam melaksanakan dan menjalankan ajaran Patuntung sebagai kepercayaan mereka.

2. Penyajian Data

Dengan mendisplay atau menyajikan data akan memudahkan untuk memahami apa yang terjadi selama penelitian berlangsung. Setelah itu perlu adanya perencanaan kerja berdasarkan apa yang telah dipahami. Dalam penyajian data selain menggunakan teks secara naratif, juga dapat berupa bahasa nonverbal seperti bagan, grafik, denah, matriks, dan tabel. Penyajian data merupakan proses pengumpulan informasi yang disusun berdasarkan kategori atau pengelompokanpengelompokan yang diperlukan.

3. Verifikasi Data

Langkah terakhir dalam teknik analisis data adalah verifikasi data. Verifikasi data dilakukan apabila kesimpulan awal yang dikemukan masih bersifat sementara, dan akan ada perubahan-perubahan bila tidak dibarengi dengan bukti-bukti pendukung yang kuat untuk mendukung pada tahap pengumpulan data berikutnya. Bila kesimpulan yag dikemukan pada tahap awal, didukung dengan bukti-bukti yang valid dan konsisten saat penelitian kembali ke lapangan mengumpulkan data, maka kesimpulan yang dikemukan merupakan kesimpulan yang kredibel atau dapat dipercaya (Sugiyono, 2007:252).

Pada tahap ini data yang telah direduksi, akan dianalisis dengan analisis deskriptif kualitatif. Data-data yang telah diperoleh dikumpulkan, kemudian diklasifikasikan, dan dianalisis secara kualitatif dengan berpedoman pada kerangka konsep yang telah dirumuskan untuk memberikan penjelasan dari fenomena yang diteliti dengan tujuan memberikan deskripsi mengenai masyarakat Kajang Dalam tentang munculnya Patuntung sebagai ajaran masyarakat Kajang Dalam, fungsi dan bentuk aplikasi dalam melaksanakan dan menjalankan ajaran Patuntung sebagai kepercayaan mereka.

\section{HASIL DAN PEMBAHASAN}

Untuk mengetahui asal usul dari pada patuntung sebagai ajaran masyarakat Kajang Dalam (ilalang embayya), serta fungsi dan aplikasinya dapat dilihat dari tanggapan- tanggapan informan yang dianggap representative dan observasi yang didapat dilapangan. Untuk lebih jelasnya akan diuraikan secara terperinci hasil wawancara sebagai berikut :

\section{Munculnya Patuntung Sebagai Ajaran Masyarakat Kajang Dalam (ilalang embayya)}

Patuntung sebagai Kepercayaan Masyarakat Kajang Dalam (ilalang embayya) inilah judul penulis angkat yang menjadi sebuah isu atau memberikan sebuah identitas bahwa Masyarakat Kajang Dalam (ilalang embayya) menganut paham patuntung walaupun dalam pengakuan secara formal bahwa masyarakat Kajang Dalam menganut paham Islam.

Untuk membuktikan bahwa Patuntung itu sebagai kepercayaan dan muncul sebagai ajaran bagi Masyarakat Kajang Dalam (ilalang embayya). Hasil wawancara dengan Puto Palasa (ammatoa) (Wawancara tanggal 7 April 2018) mengemukakan bahwa :

"Patuntung adalah panggissengan (ilmu pengetahuan) agama, negara, sejarah, silsilah'. Artinya patuntung adalah kumpulan ilmu pengetahuan baik pengetahuan agama, sejarah, dan silsilah. Lebih lanjut Puto Palasa (ammatoa) menjelaskan "selain Patuntung ada juga yang disebut mannuntungi atau tuntui yaitu orang yang mecari panggisseng (ilmu Pengetahuan) sudah pintar itumi mannuntungi." Artinya orang yang mencari ilmu pengetahuan sampai pintar disebut mannuntungi." Ada pasang yang mengatakan bahwa manuntungi pasang ri lino sampai di ahera.

Dari argumentasi informan di atas menjelaskan bahwa arti Patuntung adalah suatu pengetahuan tentang konsep keagamaan yang diyakini kebenarannya dapat menuntun atau menjadi pedoman hidup menuju keselamatan. Makna yang terkandung dalam Mannutungi yaitu orang yang pintar akan selamat di dunia sampai di akhirat. Makna Pasang tersebut carilah atau tuntutlah ilmu pengetahuan di dunia sampai di Akhirat.

Keterangan lebih lanjut yang dikemukakan oleh H. Mansjur Embas tanggal 5 Mei 2018 terkait pengertian kepercayaan Patuntung, dikatakan bahwa :

"Patuntung dan Manuntungi. Patantung adalah merupakan suatu ajaran yang dilaksanakan secara turun temurun. Yang ajarannya tallassa kamase-masea (hidup sederhana) mengutamakan kehidupan akhirat kalumanyeng 
kalupepea anjorengan. (kaya di hari kemudian). Sedangkan Manuntungi adalah orang yang melaksanakan patuntung secara tapakkoro".

"Patuntung itu suatu kumpulan ilmu pengetahuan yang berupa hubungan kepada Allah (Tu Rie A'rakna), hubungan kepada sesama manusia dan hubungan kepada alam.

Selain dari kedua pendapat di atas, lebih dipertegas oleh Abdul Haris (Wawncara tanggal 6 April 2018) juga memberikan keterangan sama bahwa pada dasarnya Patuntung diartikan "Patuntung" (Kalau diartikan kata sifat bermakna kepercayaan artinya diyakini menuju kebaikan dan keselamatan, Kalau diartikan kata kerja bermakna Penuntun artinya mengarahkan orang menuju kebaikan dan keselamatan, dan Kalau diartikan kata benda bermakna tuntunan artinya memberi petunjuk kepada orang menuju kebaikan dan keselamatan)".

Dari beberapa pernyataan yang diberikan oleh informan di atas terkait defenisi patuntung yakni suatu kepercayaan yang diyakini dimana didalamnya terdapat ilmu pengetahuan, baik pengetahuan tentang hubungan dengan Tuhan, manusia dan alam, yang dijadikan sebagai petunjuk atau pedoman hidup yang dapat menuntun manusia menuju keselamatan baik di dunia maupun di akhirat.

Hasil wawancara Jamaluddin Muslim (wawancara tanggal 19 April 2018) dimana mengemukakan asal mula munculnya ajaran patuntung menjadi ajaran bagi masyarakat Kajang Dalam (ilalng embayya) dikatakan bahwa :

"Ajaran patuntung muncul sejak adanya mula tau yang diciptakan oleh Tu Rie A'rakna, dan mengajarkan (tallasa kamase-masea di dunia dan kaya di alloanjorengan". Artinya ajaran patuntung muncul sejak adanya manusia pertama yang diciptakan oleh Tu Rie A'rakna (Allah SWT) dan mengajarkan hidup secara sederhana di dunia kaya di hari kemudian.

Keterangan lebih lanjut yang dikemukakan oleh Abdul Haris tanggal 6 April 2018 terkait ajaran Patuntung, dikatakan bahwa: "Ajaran Patuntung muncul menjadi ajaran dalam masyarakat Kajang Dalam (ilalang embayya) karena terlanjur tertanam sebelum mengenal agama merubah kebiasaan sangat sulit butuh waktu yang pajang, pada waktu itu belum ada agama".

Hal ini pula dipertegas oleh Abdul Salam sebagai Galla Lombo' dan sekaligus Kepala Desa Tanatoa (Wawancara 20 Mei 2018) mengungkapkan asal mula munculnya ajaran patuntung menjadi sebagai ajaran bagi masyarakat Kajang Dalam (ilalang embayya), bahwa :

"Patuntung bukan agama. Agamanya orang disini agama Islam. Patuntung itu suatu ajaran yang dipahami masyarakat adat ammatoa sejak bohe pertama (manusia pertama) secara turun temurun dari generasi ke generasi dimana ajaran seperti je'ne talluka Sebayang tangnga tappu dan ritual-ritual contohnya ritual u'mattang, ritual naik ri bola, ritual kematian, ritual kalomba, ritual akattere, ritual angnganro, ritual bersih kubur, ritual andingingi, ritual tunu panroli dan banyak sekali ritual-ritual yang masih dilakukan sampai sekarang'.

Dari informan di atas memiliki kesamaan dengan informan $\mathrm{H}$. Mansjur Embas (Wawancara tanggal 5 Mei 2018) yang mana mengatakan bahwa "kepercayaan Patuntung adalah salah satu bentuk kepercayaan animisme, sebelum Islam masuk ke tana kamase-masea, penyebutan Allah SWT disebut sebagai Dewa, setelah agama Islam masuk penyebutan Dewa berubah menjadi Tu Rie A'rakna. Tu Rie A'rakna dimaksud adalah Allah SWT."

Konsep Ketuhanan yang monotheis yang terhimpung dalam Pasang ri Kajang sebagaimana yang dikemukakan Puto Palasa sebagai ammatoa (wawancara, 7 April 2018):

"Tau Riyek A'rakna ammantangi ri pangnge'rakkangna, enre nissei rie'na, naki pala doang, padatonji pole nitarimana pa'nga'ratta iya toje'na". Artinya Tu Rie A'rakna (Allah SWT) tinggal berbuat sesuai kehendaknya (Tuhan melakukan sesuatu atas kehendaknya sendiri), tidak diketahui dimana adanya, diman tidak adanya, kita memohon rahmatnya. Diterimanya permintaan kita, Dia yang tentukan.

Pada hakekat keberadaan $T u$ Rie A'rakna (Allah SWT) berada dalam ruang dan waktu. Sehingga tidak diketahui secara tepat dimana Dia berkedudukan. Namun apabila $T u$ Rie A'rakna (Allah SWT) berkenan memberi rahmat dan anugrah, akan sampai kepada manusia yang dikehendaki. Meskipun Tu Rie A'rakna (Allah SWT) tidak diketahui keberadaanya, tetapi diyakini sangat dekat dengan diri manusia. Jika manusia taat menjalankan perintah-Nya dan menjauhi segala larangan-Nya, mereka akan bertemu dengan $T u$ Rie A'rakna (Allah SWT) di hari kemudian.

Dari informan di atas memiliki kesamaan dengan informan $\mathrm{H}$. 
Mansjur Embas (Wawancara tanggal 5 Mei 2018) mengemukakan bahwa :

“Anjo Tu Rie A'rakna (Allah SWT) ia ngase'na anukajariangnga anne $r i$ bohonna linoa, ia pengnga'rakangi. Penganga'rakannapi nakulle a'jari, kitte tau lino / angngira ji sa'genna pakulleta". Artinya bahwa Tu Rie A'rakna (Allah SWT) Dia yang mengetahui, menciptakan segala yang terdapat di atas bumi, Dia yang menghendaki, kehendaknyalah yang jadi. Sedangkan manusia berkehendak sesuai kemampuannya saja, pasrah/berserah diri kepada Tu Rie A'rakna. (wawancara, $5 \mathrm{Mei}$ 2018)

Menjelaskan bahwa segala sesuatunya di dunia ini hanya Tu Rie A'rakna (Allah SWT) yang Maha Mengetahui, Maha Pencipta dan Maha berkehendak, manusia hanya bisa memohon, berdoa kepada Tu Rie A'rakna (Allah SWT) sesuai kemampuan dengan pasra/berserah diri kepada Tu Rie A'rakna (Allah SWT).

Dari semua informan di atas dalam hal ini Patuntung muncul menjadi sebuah ajaran yang mengikat masyarakat Kajang Dalam (ilalang embayya) yakni bahwa dimulai dari munculnya manusia pertama yakni ammatoa (bohe pertama) yang mengajarkan kehidupan secara tallasa kamase-mase (hidup sederhana) karena menurut paham mereka hidup secara kesederhana di dunia mendapat balasan dari $T u$ Rie A'rakna yaitu kaya anjorengan (dihari kemudian) selain dari pada itu dalam kepercayaan Patuntung diajarkan kehidupan tentang bersih diri yaitu jene talluka sebayang tangnga tappu (wudhu tidak pernah batal), sembahyang secara terus menerus dan secara spritual ajaran Patuntung yakni ritual u'mattang, ritual naik ri bola, ritual kematian, ritual kalomba, ritual akattere, ritual angnganro, ritual bersih kubur, ritual andingingi, ritual tunu panroli dan banyak sekali ritual-ritual yang masih dilakukan sampai sekarang. Hal ini juga dibuktikan dari data dokumentasi yang diperoleh Penulis dilapangan, seperti ritual andingingi, ritual tunu panroli dan wawancara Abdul Salam terlihat pada lampiran 10. dokumentasi

Pemahaman masyarakat Kajang Dalam (ilalang embayya) tentang Al-Qur'an yang diturunkan oleh Tu Riyek A'rakna sebanyak 40 juz, secara ilmiah tidak ditemukan suatu pembuktian kebenarannya, karena kita ketahui bahwa firman Allah melalui Al-Qur'an sebanyak 30 juz secara tersurat (qauliyah). Kalau pemahaman mereka yang 10 juz sebagai Pasang ri Kajang merupakan difirmankan Allah yang secara tersirat atau biasa disebut ayat-ayat yang tidak termasuk dalam Al-Qur'an (kauniyah) yaitu suatu fenomena alam, persoalan hidup dan semua dinamika yang ada dalam kehidupan.

$\mathrm{Hal}$ ini pula dipertegas oleh $\mathrm{H}$. Mansjur Embas (wawancara tanggal 5 Mei 2018) mengemukakan bahwa :

"Appak mentodo ajaran kesellengan naterima bohe pertama yaitu pappanikka, baca doang rasulung, kalong tedong dan baca kalting". Artinya ada empat ajaran keislaman yang diterima Ammatoa pertama yaitu cara menikahkan, baca doang rasulung, cara memotong hewan, dan baca kalting bagi orang mati.

Kutipan data informan di atas menjelaskan bahwa dalam masyarakat Kajang Dalam (ilalang embayya) tidak melaksanakan syariat Islam secara sempurna karena dasar keislaman khususnya shalat 5 waktu, puasa, pada bulan ramadhan, zakat dan naik haji bagi orang mampu, belum mereka terima bahkan menolak ajaran Islam yang dibawah Janggo Tojerra dan Tu Asara Daeng Mallipa ditolak ammatoa, dan keduanya hanya diperkenankan disebar luaskan di luar masyarakat embayya.

Agama dan kepercayaan merupakan sesuatu yang sulit dipisahkan dari kehidupan manusia. Hal tersebut terjadi karena didalam hidupnya, manusia selalu memiliki pertanyaanpertanyaan mengenai makna hidup. Manusia juga mengalami situasi yang membuatnya berpikir akan sesuatu melampaui dirinya. Di situlah agama menawarkan jawaban-jawaban atas pertanyaan manusia. Bagi Masyarakat Kajang Dalam (ilalang embayya) sejak masuknya agama Islam antara kepercayaan patuntung dengan agama Islam, mengalami perpaduan unsur-unsur budaya lama (Patuntung) dengan unsur-unsur agama Islam sehingga kedua paham tetap nampak bahkan paham ajaran Patuntung lebih dominan dibandingkan paham ajaran Islam.

Dari hasil wawancara di atas dapat dipahami bahwa menurut paham mereka agama Islam itu berasal dari dalam Kawasan Adat Ammatoa sendiri dan disebarluaskan ke luar Kawasan Adat Ammatoa karena pada dasarnya manusia dilahirkan kebumi ini sudah beragama dikarenakan. Hasil observasi Penulis dilapangan berbeda dengan apa yang dikatakan informan bahwa agama Islam itu berasal dari Kajang Dalam (ilalang embayya) dikarenakan secara universal agama Islam diketahui bahwa berasal 
dari Jazira Arab dan ditambah dari referensi yang ada pada buku yang ditulis oleh Sambu berjudul Sejarah Kajang yang mana menjelaskan bahwa agama Islam masuk ke Kajang setelah kerajaan Gowa, Luwu dan Bone menerima ajaran agama Islam secara resmi sekitar abad ke17 yang disebarkan oleh Abdul Jawad yang bergelar Datu di Tiro, dan kita fahami bahwa perbedaan itu adalah sesuatu hal yang lumrah terjadi.

Hasil wawancara Puto Topo (Wawancara tanggal 6 April 2018) menjelaskan bahwa perpaduan antara ajaran Patuntung dengan ajaran Islam sebagaimana dalam Pasang ri Kajang dijelaskan bahwa :

"Guru sara'a tangattappa ri patuntunga ta la assai kaguruanna, guru patuntung tanggatappa ri guru sara'a ta la assai kepatuntunganna". Artinya guru agama tidak percaya kepada guru patuntung tidak sah gurunya sedangkan guru patuntung tidak percaya kepada guru agama tidak sah kepatuntungannya.

Hal ini pula dipertegas oleh $\mathrm{H}$. Mansjur Embas (wawancara tanggal 5 Mei 2018) sebagaimana dalam Pasang ri Kajang dijelaskan bahwa :

"Je'ne talluka, sembayang tangngatappu". Artinya wudhu yang tak batal, sembayang terus menerus".

Kedua Kutipan data informan di atas nampak jelas bahwa suatu cara bagi masyarakat Kajang Dalam (ilalang embayya) untuk beradaptasi dengan ajaran Islam. Sehingga kehidupan keagamaan masyarakat Kajang Dalam (ilalang embayya) menampilkan fenomena unik yaitu perpaduan unsur kepercayaan patuntung dengan unsur ajaran Islam, sehingga apabila salah satu unsur-unsur kepercayaan yang dihilangkan maka mengakibatkan hilangnya keseluruhan unsurunsur tersebut

\section{Fungsi Kepercayaan Patuntung dalam Kehidupan Masyarakat Kajang Dalam (ilalang embayya)}

a. Pantuntung sebagai fungsi ajaran

Dalam hubungannya dengan manusia, kepercayaan Patuntung berfungsi sebagai tuntunan hidup atau pedoman hidup dalam hubungan dengan sesama, dimana kepercayaan Patuntung memiliki konsep ajaran yang besumber dari Pasang ri Kajang mengajarkan hidup tallasa kamase-mase (hidup sederhana), selanjutnya Patuntung berfungsi mengajarkan hubungan manusia dengan alam dan Patuntung mengajarkan hubungan manusia dengan Tuhan.

Hasil wawancara Abdul Haris salah satu tokoh pendidik (wawancara tanggal 6 April 2018) menjelaskan bahwa :

"Fungsi Patuntung dapat memberikan pelajaran dan petunjuk atau jalan yang benar dalam kehidupan manusia. Pengetahuan yang didapatkan penganut patuntung melalui pendidikan non formal yang sumber ajarannya dari Pasang ri Kajang yang mengajarkan tallasa kamase-mase, mengajarkan sifat jujur, tegas, sabar dan pasrah, dan meyakini kekuasaan $T u$ Rie A'rakna (Allah SWT)". Ammatoa bersama pemangku adatnya sebagai fungsi utama dalam keberhasilan.

Selanjutnya informan atas nama $H$. Mansjur Embas menambahkan konsep ajaran patuntung yang terhimpun dalam pasang mengajarkan nilai-nilai budaya yang sifatnya anjuran dan nilai-nilai budaya yang sifatnya larangan, yang dijadikan sebagai pedoman atau petunjuk dalam berinteraksi kepada sesama manusia, kepada alam dan Tuhan, dimana menjelaskan bahwa ada nilai-nilai yang menjadi anjuran dan larangan :

1. Nilai-nilai ajaran patuntung yang menjadi anjuran : (a) Punna lingkako na rie katinting ri annuranng pasalai (Kalau ada katinting di jalan disingkirkan atau kalau ada rintangan dijalan tolong disingkirkan), bermakna anjuran agar seseorang senantiasa melakukan sesuatu yang oleh orang lain merasakan manfaatnya, (b) Ruppai laloi / timbarangngi pau haji padannu tau (tengurlah sesama manusia dengan ucapan yang menyenangkan) (c). Katutui buah babamu, timba babamu mangimai kedua pajijiannu (hormati dan hargailah kedua orang tua) (d). Sikatutuiko sipetta sipake tangaalate ri pakkelebineannu (saling menghormati, saling menghargai, saling mencintai di dalam kehidupan rumah tangga) (e) Riekko sipamentengan rigau sitinajaea (selalu berbuat sesuai dengan norma norma), (f) Akkaresoko iya sitinajayya risese pakkulenu (bekerja sesuai kemampuan) atau mengajaran etos kerja, (g) Urangi rikamengeangnnu narea ripare to rie arakna (ingatlah selalu akan akhir hayatmu, karena kita ini diciptakan dan menyembah kepada to rie arakna atau selalu mengingat kematian 
2. Nilai-nilai budaya yang sifatnya larangan yaitu: (a). Ako karesoi apa apa mamo namai naitingi sogo padannu rupa tau (jangan mengambil apa-apa yang sudah ditetesi keringat orang atau memiliki sesuatu barang kalau barang itu sudah milik orang lain atau jangan mengambil hak orang lain bisa juga ditafsirkan jangan mencuri), (b) Ako allei kayu tassajeng (jangan ambil kayu yang sudah sandar atau jangan menganggu gadis yang sudah dipinang atau sesuatu yang sudah dimiliki orang tidak boleh lagi diambil), (c) Ako

allingkai batang (jangan melangkahi batang kayu atau jangan mengambil kayu kepunyaan orang atau ditafsirkan jangan menganggu atau bersinah kepada wanita yang sudah bersuami), (d). Ako angakengi gau appatuppu ere (jangan berusaha mengalirkan air ke tempat yang tinggi) artinya diajarkan berbuat sesuai norma yang sesuai pasang atau jangan berbuat yang tidak sesuai dengan norma-norma yang berlaku. (Wawancara tanggal 5 Mei 2018)

\section{Pembahasan}

Berkaitan dengan kegiatan keagamaan yang dipratekkan oleh berbagai suku bangsa di Indonesia dalam berbagai upacara adat ataupun terhadap pemujaan roh leluhurnya dianggap sebagai aliran kepercayaan, seperti animisme dan dinamisme. Namun setelah masuknya agama-agama besar (Hindu, Budha, Kristen, dan Islam), kepercayaan animisme dan dinamisme berangsur-angsur surut, meskipun tidak hilang sama sekali.

Pada khususnya masyarakat Sulawesi Selatan, terdapat beberapa komunitas adat yang memiliki identitas sistem kepercayaan yang mereka anut, seperti di Toraja dikenal dengan Aluk Todolo dengan sistem kepercayaan terhadap Tuhan yang disebut Puang Matoa; di Sidrap dikenal dengan Toani Tolotang dengan sistem kepercayaan terhadap Tuhan yang disebut Dewata Seuwae yang bergelar Patotoe; dan di Kajang dikenal Patuntung dengan sistem kepercayaan kepada Tuhan yang disebut Turie, A'rakna.

Hasil Penulisan yang didapatkan di lapangan menunjukkan Patuntung muncul sebagai ajaran masyarakat Kajang Dalam, fungsi Patuntung dan bentuk aplikasi Patuntung dalam kehidupan keseharian.

\section{Patuntung munculnya sebagai ajaran masyarakat Kajang Dalam (ilalang embayya)}

Patuntung sebagai kepercayaan masyarakat Kajang Dalam (ilalang embayya) menjadi sebuah identitas dimana mereka menganut paham ajaran Patuntung, secara tidak lansung mereka juga mengaku beragama Islam. Dalam praktek keagamaan yang sesuai ajaran Islam yang sifatnya umum seperti sembahyang, puasa dan naik haji bagi yang mampu sangat kurang bahkan sama sekali tidak dilaksanakan, mereka melakukan dengan cara mereka sendiri sesuai pahamnya, dan berusaha keras menjauhkan diri dari perbuatan yang tercela. Mereka memahami ajaran Islam melalui penghayatan batiniah (secara hakiki) dan terwujud dalam bentuk sikap dan perilaku sehari-hari.

Secara etimologi Patuntung adalah suatu kepercayaan yang diyakini dimana didalamnya terdapat ilmu pengetahuan, baik pengetahuan tentang hubungan manusia dengan Tuhan, hubungan manusia dengan sesama, dan hubungan manusia dengan lingkungan alam, yang dijadikan sebagai petunjuk atau pedoman hidup yang dapat menuntun manusia menuju keselamatan baik di dunia maupun di akhirat.

Dari pengalaman penulis sejak tahun 2001 sampai sekarang penulis sudah termasuk bagian dari masyarakat Kajang karena menikah dengan orang Kajang dan tinggal di Kajang tentu sedikit banyaknya pengetahuan dan pengalaman yang dipahami penulis menambah kebenaran judul yang diangkat, dan melakukan observasi langsung kepada masyarakat Kajang selama 3 bulan dan tak satupun warga secara terang-terangan mengatakan bahwa mereka penganut Patuntung, dengan melihat perilaku keagamaan yang dilakukan sejak Bohe Pertama atau manusia pertama yang digelar ammatoa bahwa Patuntung itu suatu kepercayaan yang diyakini eksistensinya.

Untuk membuktikan Patuntung sebagai ajaran yakni dimana masyarakat Kajang Dalam (ilalang embayya) meyakini bahwasanya Patuntung bukan agama melainkan suatu hasil ciptaan manusia yang dijadikan sebagai keyakinan yang wajib dipatuhi dan dilaksanakan oleh setiap anggota masyarakat yang ada dalam Kawasan Adat Ammatoa, sebagai "tuntunan" untuk mengamalkan ajaran kebenaran kepada manusia menuju keselamatan baik di dunia maupun di akhirat yang diwasiatkan dan 
diwariskan secara lisan oleh para leluhur mereka secara turun-temurun dari generasi kegenerasi.

Awal mula munculnya Patuntung dilihat dari aspek ajarannya dan setelah masuknya agama Islam mengalami transformasi dalam skala kecil. Asalnya ajaran Patuntung diyakini masyarakat Kajang Dalam (ilalang embayya) dimulai dari munculnya manusia pertama yakni ammatoa (bohe pertama) dengan sumber ajarannya Pasang ri Kajang yang mengajarkan kehidupan secara tallasa kamasemase (hidup sederhana) karena menurut paham mereka hidup secara kesederhanaan di dunia dan mendapat balasan dari Tu Rie A'rakna yaitu kaya anjorengan (di hari kemudian).

Selain dari pada itu dalam kepercayaan Patuntung mengajarkan kehidupan tentang bersih diri yaitu je'ne ta'luka sembajang tangnga tappu (wudhu tidak pernah batal), sembayang secara terus menerus dan secara spiritual ajaran Patuntung yakni ritual u'mattang (pemberian sesaji kepada roh), ritual naik ri bola (upacara naik rumah), ritual kacappukan uтиги (ritual kematian), ritual kalomba (ritual menghindari penyakit anak-anak), ritual akattere (ritual naik haji), ritual angnganro (ritual doa bersama), ritual tangkasi jera (ritual bersih kubur), ritual andingingi (upacara mendinginkan seluruh isi alam), ritual tunu panroli (upacara kutukan untuk pelanggar adat) dan banyak sekali ritual-ritual yang masih dilakukan sampai sekarang.

Kepercayaan Patuntung menimbulkan keyakinan dan ketaatan bagi masyarakat Kajang Dalam (ilalang embayya), mereka percaya adanya dunia gaib, percaya pada kekuatan supranatural. Inilah yang melahirkan fanatisme. Dan apa yang diyakini itu sangat bersifat abstrak dan berada diluar pergaulan hidup sehari-hari, sehingga para penganut Patuntung melakukan berbagai bentuk pemujaan atau ritual-ritual dan simbol-simbol.

Masyarakat Kajang Dalam (ilalang embayya) sebelum masa Pra Islam. Kepercayaan Patuntung adalah salah satu bentuk kepercayaan animisme sebelum Islam masuk dalam Kawasan Adat Ammatoa. Kepercayaan Patuntung sangat berpegang teguh pada Pasang ri Kajang. Dalam Pasang ri Kajang disebutkan, bahwa alam semesta ini diciptakan oleh Tu Rie A'rakna. Pada masa Pra Islam dikenal dengan nama Dewa atau Batara. Setelah Islam masuk, Tu Rie A'rakna dimaksud Allah SWT.

Konsep Monothaeime dalam kepercayaan Patuntung muncul setelah ajaran agama Islam masuk di Kawasan Adat Ammatoa dengan penyebutannya Tu Rie A'rakna (Allah SWT) atau Tuhan Yang Maha Berkehendak. Keyakinan tunggal, bagi masyarakat Kajang Dalam (ilalang embaya), kerena mereka tidak mau dikatakan musrik menduakan Tuhan. Mereka percaya bahwa apabila terdapat lebih dari satu Tuhan, maka dunia menjadi tidak tentram dan kacau.

Konsep Ketuhanan yang monotheis yang terhimpung dalam Pasang ri Kajang yang berbunyi :

"Tau Riyek A'rakna ammantangi ri pangnge'rakkangna, enre nissei rie'na, naki pala doang, padatonji pole nitarimana pa'nga'ratta iya toje'na". Artinya Tu Rie A'rakna (Allah SWT) tinggal berbuat sesuai kehendaknya (Tuhan melakukan sesuatu atas kehendaknya sendiri), tidak diketahui dimana adanya, diman tidak adanya, kita memohon rahmatnya. Diterimanya permintaan kita, Dia yang tentukan.

Hakekat keberadaan Tu Rie A'rakna (Allah SWT) berada dalam ruang dan waktu. Sehingga tidak diketahui secara tepat di mana Dia berkedudukan. Namun apabila $T u$ Rie A'rakna (Allah SWT) berkenan memberi rahmat dan anugrah, akan sampai kepada manusia yang dikehendaki. Meskipun Tu Rie A'rakna (Allah SWT) tidak diketahui keberadaanya, diyakini sangat dekat dengan diri manusia. Jika manusia taat menjalankan perintah-Nya dan menjauhi segala larangan-Nya, mereka akan bertemu dengan Tu Rie A'rakna (Allah SWT) di hari kemudian.

Kemahakuasaan Tu Rie A'rakna (Allah SWT) dalam alam semesta ini tidak terbatas, segala sesuatu di dunia ini hanya Tu Rie A'rakna (Allah SWT) yang Maha Mengetahui, Maha Pencipta dan Maha berkehendak, manusia hanya bisa memohon, berdoa sesuai kemampuan dengan pasra/ berserah diri kepada $T u$ Rie A'rakna (Allah SWT)

\section{Simpulan dan Saran}

Dari hasil penelitian disimpulan: (1) Munculnya kepercayaan Patuntung pertama kali dimulai dari munculnya manusia pertama yakni ammatoa (bohe pertama) dengan sumber ajarannya Pasang ri Kajang yang mengajarkan kehidupan secara hidup sederhana, hidup dalam keadaan bersih, sembahyang secara terus menurus, dan ritual-ritual dalam ajaran Patuntung masih dilakukan sampai sekarang; (2) 
Fungsi kepercayaan Patuntung bagi masyarakat Kajang Dalam (ilalang embayya) yakni sebagai tuntunan hidup atau pedoman hidup dalam hubungan manusia dengan Tuhan, hubungan manusia sesama manusia, hubungan manusia dengan lingkungan alam dengan melihat wujud fungsinya sebagai fungsi ajaran, penyelamat, kontrol sosial, dan pemersatu; (3) Aplikasi kepercayaan Patuntung dalam kehidupan keseharian masyarakat Kajang Dalam (ilalang embayya) yakni bagaimana kepercayaan Patuntung dalam hubungan dengan $\mathrm{Tu}$ Rie A'rakna (Allah SWT) dengan cara mengarahkan jadi dirinya baik aspek rohani maupun aspek jasmani dengan memperaktekkan je'ne talluka sembajang tangngga tappu (wudhu tak batal dan sembahyang terus menerus) dan tafakkoro (tafakur), melakukan pa'nganroang (ritual berdoa bersama) serta melakukan ibadah sesuai syariat agama Islam dengan menurut pahamnya sendiri. Sedangkan aplikasi kepercayaan Patuntung dalam kehidupan keseharian dilihat dari wujud konkrit tallasa kamase-mase (hidup sederhana) yaitu tanah sederhana, rumah sederhana, dan pakaian sederhana serta tidak pakai alas kaki, dan terakhir aplikasi kepercayaan Patuntung dalam kehidupan keseharian dalam hubungannya dengan lingkungan alam dilihat dari aspek riligius dan aspek ekologis. Dengan cara demikian masyarakat Kajang Dalam (ilalang embayya) kepercayaan Patuntung diyakini sebagai jalan untuk mendapatkan belahan kasih dari Tu Rie A'rakna (Allah SWT) melalui apisona (pasrah) diterima tidaknya bukalah soal utama yang penting ialah niat melakukan upaya maksimal menuju allo anjorengang (hari kemudian).

Sehubungan dengan kesimpulan di atas, maka penulis ingin mengemukakan saran-saran sebagai berikut: (1) Bagi masyarakat Kajang Dalam (ilalang embayya) ajaran Patuntung yang pada hakikatnya harus direalisasikan dengan perpaduan syariat agama Islam yakni 1) sholat 2) puasa dan 3) haji secara konkrit; (2) Pemerintahan dengan adat Ammatoa sekiranya tetap melestarikan atau menjaga nilai-nilai ajaran Patuntung agar tidak tergerus oleh arus globalisasi, dalam hal ini tallasa kamase-masea (hidup sederhana) senantiasa dilaksanakan sebagai aktivitas sehari-hari bagi masyarakat Kajang Dalam (ilalang embayya); (3) Adapun bagi pembaca, materi dari hasil Tesis ini dapat dijadikan sebagai pengetahuan untuk menanamkan sikap tallasa kamase-masea (hidup sederhana) sebagai jalan hidup dan bagi peneliti selanjutnya dapat dijadikan referensi.

\section{DAFTAR RUJUKAN}

\section{Ali, Abdullah. 2007. Sosiologi Pendidikan dan} Dakwah. Cirebon: STAIN Press.

Abu, Hamid,dkk 1979. Penelitian Potensi Perekonomian Daerah Sulawesi Selatan : Suatu Studi Identifikasi SosioAntropologi Ekonomi Tentang Tanah, Wiraswasta dan Migrasi Keluar, Proyek Penelitian "Dinamika Masyarakat" Ujung Pandang : Leknas LIPI Kerjasama dengan Universitas Hasanuddin

Arman, B. 2016. Aplikasi Ajaran Patuntung Dalam Komunitas Adat Ammatoa Desa Tanah Towa, Kecamatan Kajang, Kabupaten Bulukumba. (Artikel Online) diakses 10 Februari 2018.

Akib, Yusuf. Potret Manusia Kajang, Makassar : Pustaka Refleksi, 2003

Brata, Trisnu Nugroho. 2007. Antropologi Untuk SMA dan MA Kelas XII. Jakarta : Erlangga (Esis)

Gerertz Clifford, 1992, Kebudayaan \& Agama. Yogyakarta : Kanisius

Grathoff, Richard. 2000. Kesesuaian Antara Alfred Schutz dan Talcott Parsons: Teori Aksi Sosial. Jakarta: Kencana.

Hafid, Abdul. 2013. Sistem Kepercayaan pada Komunitas Adat kajang Desa Tana Toa

Kecamatan Kajang Kabupaten

Bulukumba.(Artikel Online) diakses 1 Februari 2018.

Haviland, William A. 1999. Antropologi. Jilid 1. (Alih bahasa R.G. Soekadjo). Jakarta:

Erlangga.

Katu, Samiang, Local Islam In Indonesia : Religion "Patuntung" In Kajang, JICSA 03 No 02 (2014)

Koenjaraningrat. 1980. Sejarah Teori Antropologi. Jakarta: UI. Press. 
Phinisi Integration Review. Vol 2(2) Agustus 2019

Koenjaraningrat. 1985. Pengantar Ilmu Antropologi. Jakarta: Aksara Baru.

Koenjaraningrat. 1992. Beberapa Pokok Antropologi Sosial. Jakarta: Dian Rakyat.

Koenjaraningrat. 1997. Metode Penelitian Masyarakat. Gramedia : Jakarta

Koenjaraningrat. 2000. Pengantar Ilmu Antropologi. Jakarta: Reneka Cipta.

Munarfah dan Hasan. 2009. Metode Penelitian. Makassar: Prasse.

Moleong, Lexy J. 2012. Metodologi Penelitian Kualitatif. Edisi Revisi. Bandung: Remaja Rosdakarya.

Maryaeni. 2005. Metode penelitian kebudayaan. Jakarta :Bumi aksara 